\title{
Uma experiência de criatividade no ensino de Jornalismo na pós-graduação
}

\author{
Antonio Teixeira de Barros*
}

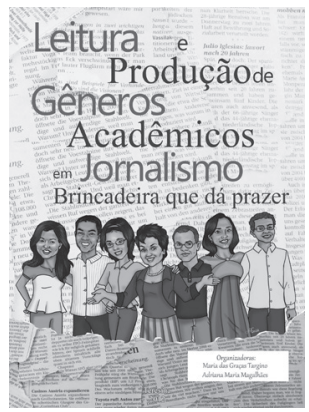

TARGinO, M. das G.; MAGAlHÃES, A. M. (Orgs.) Leitura e produção de gêneros acadêmicos em jornalismo: brincadeira que dá prazer. Teresina: EdUFPI, 2012. 144p.

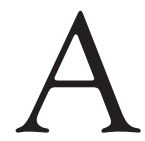
obra Leitura e produção de gêneros acadêmicos em Jornalismo; brincadeira que dá prazer resulta da seleção de textos produzidos por alunos e professores de curso de pós-graduação em Jornalismo da Universidade Federal do Piauí (UFPI). Trata-se de iniciativa cujo mérito principal é dinamizar e renovar as práticas pedagógicas relacionadas ao ensino de Jornalismo, tornando a pós-graduação um espaço de inovação acadêmica. A produção, coordenada pela profa. dra. Maria das Graças Targino, ocorreu a partir de um eixo temático: os gêneros textuais e suas diversas formas de apresentação, o que possibilitou à turma aliar o estudo de uma temática curricular com a exploração de formatos criativos, em um contexto de reconfiguração e redefinição dos próprios gêneros. A coletânea apresenta um apanhado do resultado textual de um conjunto de dez atividades realizadas mediante técnicas,

\footnotetext{
* Docente e pesquisador do Programa de Mestrado em Ciência Política do Centro de Formação (CEFOR) da Câmara dos Deputados, Brasília-DF, Brasil. Doutor em Sociologia e mestre em Comunicação.
} 
recursos e dinâmicas variadas, incluindo redação a partir da observação direta de cenários e situações urbanas, produção parafrástica tendo material jornalístico, músicas e filmes como pretextos, além de produção textual livre dos alunos.

A análise do escopo da proposta, aliada ao conjunto dos textos, permite algumas observações e comentários em termos de perspectivas teóricas que conectam o Jornalismo e o contexto educativo- universitário e a relação da universidade com as mídias locais. Mas o livro também remete a outras abordagens caras ao campo educacional, tais como a educação difusa e a conexão das práticas educativas com o campo experiencial e as tramas cotidianas.

Sob o prisma teórico, é relevante ressaltar que os gêneros constituem o ponto de articulação entre os aspectos econômicos e culturais dos bens produzidos pelas indústrias culturais e sua dimensão simbólica, pois o sujeito que as produz mobiliza recursos, baseia-se em regras e implementa esquemas para atingir um receptor específico. Isso confirma o pressuposto dos estudos culturais acerca da interdependência entre as instâncias da produção e da recepção. $O$ gênero, portanto, é a ponte entre as esferas da produção e da recepção, com interferências múltiplas sobre ambas. Afinal, docentes e estudantes atuam como intérpretes de sentido do ambiente universitário e se relacionam com os demais agentes do mundo social e da cultura que dá suporte social à universidade e suas práticas de formação e inovação cultural. São intérpretes políticos do seu contexto, a partir da relação com suas fontes de informação, os demais atores sociais, com os quais interagem nas suas rotinas e dinâmicas decorrentes de suas atividades acadêmicas, além de suas habilidades para a observação e análise da realidade.

Outro aspecto a ser destacado é a conexão da proposta pedagógica com o contexto da cultura local, o que se revela pela divulgação de boa parte dos textos dos estudantes da disciplina em jornais, revistas e portais integrados às mídias locais. Ao mesmo tempo em que conferem visibilidade a uma iniciativa da universidade, as publicações também atuam como insumos simbólicos para dinamizar a esfera da discutibilidade pública, uma vez que se trata de textos que estimulam a reflexão e a discussão. Portanto, além 
de resultar de uma atividade pedagógica, tal produção também atinge o nível da educação difusa, do ponto de vista dos leitores e dos veículos locais que publicam os textos. Esse nível educativo difuso abrange a dimensão extraescolar de formação cultural.

Tal escopo analítico da obra em exame, mesmo não figurando em primeiro plano, envolve uma concepção de educação integrada às relações sociais e atividades do cotidiano, isto é, as relações educativas não especializadas e não regulamentadas, inseridas nas novas dinâmicas de socialização e aprendizagem da chamada "modernidade líquida" e da "sociedade aprendente". Em termos práticos, essa rede articula, institui e produz enquadramentos ou molduras socioculturais para que os cidadãos possam dispor de ferramentas cognitivas de compreensão do mundo e dos processos sociais, incluindo o campo da educação e da cidadania.

São relações socioculturais ancoradas nas dinâmicas do cotidiano. A observação do cotidiano, aliás, é um dos eixos que orienta a produção dos textos. Assim, tanto os educadores como os profissionais do campo da mídia traduzem as informações oriundas do "mundo vivido" e, desse modo, contribuem para (re)configurar o espaço argumentativo no ambiente social, na perspectiva da educação difusa. Essa atuação em rede, com suas estruturas de mediação simbólica e cultural funciona como catalisador para a construção de trilhas sociais e culturais de interpretação da complexidade das pautas educativas e culturais no contexto atual. Afinal, a educação e a mídia constituem dois campos fundamentais da reprodução e da renovação cultural e do fortalecimento das redes de capital social.

Do ponto de vista do conteúdo, os textos publicados na coletânea, apontam pistas para fomentar o debate corrente sobre o dinamismo do atual contexto cultural. Afinal, vivemos em uma época de redefinição dos vínculos sociais e de mudança nas configurações sociais, com as mediações tecnológicas. Com efeito, se TV reambientou o lazer na privacidade doméstica e alterou a configuração dos contatos interpessoais, o compartilhamento de conteúdos pela internet, em certa medida, resgata a dimensão das relações de reciprocidade, essenciais para a vida social. 
Dessa perspectiva, o compartilhamento de conteúdos gera novas escalas de proximidade, o que implica a reinvenção de relações e de laços sociais, além de reavivar formas de reciprocidade. Desse ponto de vista, é relevante que a própria universidade se torne um espaço para fomentar esse processo, a exemplo da experiência pedagógica aqui relatada. Uma iniciativa que contribui para renovar as práticas e dinâmicas do ensino do Jornalismo, estimular a formação crítica de novos jornalistas e potencializar o papel do Jornalismo no âmbito da inserção social de conteúdos e da educação difusa, pilares de uma cultura cívica ativa, participativa e vigilante do ponto de vista cidadão. Além disso, a visibilidade de práticas pedagógicas inovadoras e criativas pode suscitar a reflexão não só no campo em que elas surgem, mas também nas esferas sociais em que elas repercutem, inclusive em áreas afins. No caso em tela, além do Jornalismo, podemos considerar as diversas áreas correlacionadas, além da educação de modo mais abrangente. 